\title{
RESENHAS
}

DOI: http://dx.doi.org/10.1590/So034-759020170510

\section{REPENSAR E REAPRENDER NA ERA PÓS-DIGITAL}

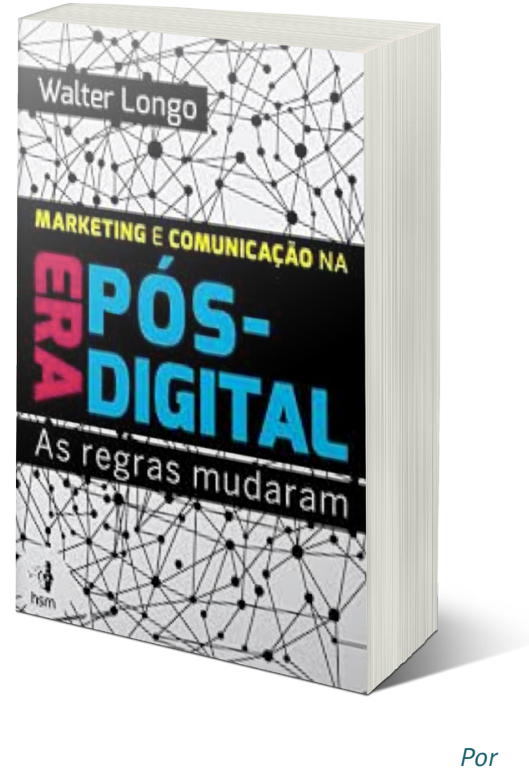

LUCAS RODRIGO SANTOS DE ALMEIDA lucasalmeidarecife@gmail.com Graduado em Administração pela Faculdade Joaquim Nabuco, Recife - PE, Brasil

\section{MARKETING E COMUNICAÇÃO NA ERA PÓS-DIGITAL: AS REGRAS MUDARAM}

De Walter Longo. São Paulo, SP: HSM do Brasil, 2014. 312 p.

O atual cenário globalizado possibilitou a mutabilidade de conceitos, valores e negócios numa velocidade ímpar. Desse modo, as mudanças no cenário corporativo vão desde o ingresso de novas tecnologias em vários segmentos até a alteração dos hábitos de consumo da sociedade. 0 fenômeno da tecnologia colaborou para possíveis modificações na mentalidade de empreendedores, executivos e profissionais em geral. Por outro lado, esta nova era afetou as relações no cotidiano, seja no âmbito social, acadêmico ou profissional.

Esse conceito é defendido pelo publicitário Walter Longo. Para o autor, uma revolução acontece a partir da adoção de novos comportamentos da sociedade. Essa revolução comportamental está atrelada à realidade cotidiana, em que a conexão digital entre as pessoas ocorre de modo natural, porém estas só percebem a importância da tecnologia quando ela falta. A consequência desse comportamento fez surgir jargões criados pelos nativos digitais, como: "tal lugar é mesquinho, nem rede wi-fi oferece". Ou seja, as pessoas utilizam a rede de maneira natural por meio de seus smartphones, tablets e, independentemente do lugar em que estejam, sentem a necessidade de estarem conectadas. Essa realidade é comparada pelo autor com outras invenções ao longo da história, como fogo, metal e vapor, enfatizando o surgimento da eletricidade, pela qual as pessoas tinham fascínio, medo e admiração, porém, para tornar-se ubíqua, a luz elétrica levou décadas, e, atualmente, é algo comum, no qual as pessoas só lembram de sua existência quando ela falta.

0 autor incita as empresas e gestores da área de Comunicação e Marketing para a construção de uma alma digital para os seus negócios. Esse conceito, segundo o autor, seria, portanto, uma nova cultura ou dimensão organizacional que iria muito além da construção de sites, blogs, redes sociais, página no Youtube etc. Para o autor, esse conceito permitirá às empresas de Comunicação implementarem sistemas mais colaborativos, com incentivo a reuniões por videoconferência e revendo as estruturas hierárquicas. 
Nesta obra, o autor apresenta cases de empresas digitais, inclusive as que ele presidiu. Ele exemplifica como o Facebook e o Google estão comportando-se perante o fenômeno da pósdigitalidade. Dessa maneira, essas organizações possuem, mais do que ferramentas digitais, uma alma digital que busca a criação do futuro delas e de todos, consequentemente, rompendo e desafiando paradigmas gerenciais presentes desde os tempos de Taylor e Fayol.

O livro divide-se em três partes. Na parte I, “O novo espelho de Narciso", com quatro capítulos, o autor discorre a respeito da inveja como um dos pecados capitais. Mas qual o motivo desse questionamento em relação à era pós-digital? Em tempos não muito remotos, os consumidores utilizavam as mídias digitais de maneira social como sinônimo de status, poder e autoestima elevada. Atualmente, porém, existem a ubiquidade e a democratização do universo pós-digital, pelas quais todas as pessoas podem acessar seus iPhones sem qualquer tipo de "resgate" do status quo. Nos capítulos posteriores, o autor faz uma ressalva em relação à gestão empresarial, que, na maioria dos casos, preocupa-se mais com a pendência do que a tendência, tornando o gerenciamento do tempo fundamental, pois as mudanças afetarão o destino da empresa. Ainda nessa seção, o autor expõe um relato do vocalista da banda Iron Maiden, Bruce Dickinson, a respeito da incapacidade das gravadoras de se reinventarem diante da nova realidade digital, na qual elas poderiam criar sites de downloads gratuitos, e incentivar os músicos a desenvolverem conteúdos inéditos e exclusivos para os seus fãs.

A parte II do livro, "Paradigmas estilhaçados", contém quatro capítulos. Longo recorre a antigos questionamentos do universo empresarial que são considerados tabus. Sobre a questão “Tamanho é documento?", o autor cita o caso do WhatsApp, que, antes de ser comprado pelo Facebook, era uma empresa que contava apenas com 55 empregados, mas a negociação da startup gerou uma receita de vários bilhões de dólares. Para responder a questões como: O cliente tem sempre razão? O segredo é a alma do negócio? O ótimo é inimigo do bom?, o autor posiciona-se de modo abrangente a respeito dos profissionais de propaganda, que poderiam oferecer um atendimento mais consultivo e pedagógico ao cliente (empresa ou consumidor) em relação à propaganda a ser desenvolvida. Ele ainda comenta que os projetos nas organizações não devem ser expostos à concorrência, porém o grau de envolvimento de todos "não combina com o nível de segredo e individualismo".

A parte III, “Um novo começo", finaliza a obra, em sete capítulos. 0 autor identifica as características da era pós- digital, assim como a efemeridade do consumidor. Em relação a esse último, Longo apresenta uma reflexão pertinente ao afirmar que as pessoas no universo pós-digital transitam nas redes sociais e mudam de opinião constantemente, destarte ocasionando uma ausência de fidelidade dos consumidores às marcas. 0 autor discorre sobre a macrotendência da internet das coisas, na qual seres humanos e computadores terão uma “interação simbiótica” a partir de geladeiras, fornos, fogões e outros. Longo identifica que esta era pós-digital caminha por um processo sincrônico a partir da identificação das experiências e momentos vividos pelos consumidores, e não apenas por dados demográficos, como idade, sexo, escolaridade, cor etc. Por fim, o autor aborda a relevância de novas ideias tanto nos negócios como na carreira do profissional, pois considera que tanto a empresa como o profissional são mídias, que se expressam e atuam de modo consciente. A partir da ideia "sem tensão não há atenção", Longo apresenta as narrativas que uma marca pode carregar e como o grau de tensionalidade com o cliente gera surpresa, atenção e afeto. E, no último capítulo, o autor faz uma analogia do cenário pós-digital com um circo, por entender que os malabarismos, o sincronismo e a efemeridade ocorrem de maneira constante, gerando-se uma gestão complexa que poderá levar ao sucesso a partir da conexão entre as partes envolvidas. Nesse contexto, esse é o conceito "ideal” para a direção e a coordenação de uma empresa no mercado, com a participação de todos os colaboradores, sem nenhum caráter utópico.

Os aspectos abordados na obra de Longo apresentam ao leitor reflexões quanto às mudanças no cenário corporativo mundial com foco na área de Marketing e Comunicação. Em contrapartida, apesar de citar em alguns trechos a experiência de profissionais que atuam em outros segmentos, a obra discorre sobre a tecnologia digital como ferramenta competitiva e estratégica para o mercado de propaganda. Dessa forma, a obra apresenta lacunas que poderiam ser preenchidas e exploradas a partir do uso da tecnologia no ambiente interno da organização em áreas como Logística, Recursos Humanos, Finanças, Administrativo e outras. Outro ponto a ser debatido está na utilização da tecnologia nos pequenos negócios, visto que, muitas vezes, o microempreendedor não dispõe de capital intelectual para a utilização dessas ferramentas digitais. Como sugestão de livro, o Adeus Facebook: 0 mundo pós-digital, de Jack London (Editora Valentina, 2013), que explora de modo abrangente a era pós-digital do ponto de vista do empreendedor, avaliando oportunidades, ameaças e tendências do comércio eletrônico e das redes sociais. 